\title{
Presence of sorbin in human digestive tract and endocrine digestive tumours
}

\author{
F Abou El Fadil-Nicol, F Berger, M Descroix-Vagne, D Pansu
}

\begin{abstract}
Background-Sorbin, a 153 amino acid peptide isolated from porcine intestine, was localised by immunohistochemistry in endocrine cells of the intestinal mucosa and pancreas and in the enteric nervous system in the pig.

Aims-To identify sorbin cells in normal human digestive tissues and to explore the expression of sorbin in 37 digestive endocrine tumours: 14 intestinal carcinoid tumours and 23 endocrine pancreatic tumours including six insulinomas.

Methods-Two polyclonal antibodies against the $\mathrm{C}$-terminal and the $\mathrm{N}$-terminal sequences of porcine sorbin raised in rabbit were used to evaluate sorbin expression by immunohistochemistry.

Results-In the human digestive tract, sorbin, characterised by both $\mathrm{C}$-terminal and $\mathrm{N}$-terminal immunoreactivity, was found in enterochromaffin cells of the gastric and intestinal epithelium from the pyloric junction to the descending colon. C-Terminal sorbin immunoreactivity alone was found in plexii from the enteric nervous system and in some insulincontaining cells of normal pancreas. $\mathrm{C}$-Terminal and $\mathrm{N}$-terminal antibodies disclosed sorbin in five of 14 intestinal carcinoid tumours; C-terminal antibody alone disclosed a $\mathrm{C}$-terminal sorbin peptide in two of six insulinomas and three of 17 endocrine pancreatic tumours. The presence of sorbin was not associated with a specific clinical syndrome.
\end{abstract}

Conclusions-Sorbin is present in the digestive tract in several forms. It is expressed in some intestinal and pancreatic endocrine tumours.

(Gut 2000;46:182-190)

Hôpital 69437 Lyon Cedex 03, France

F Abou El Fadil-Nicol M Descroix-Vagne

Ecole Pratique des Hautes Etudes

D Pansu

Laboratoire

d'Anatomie

Pathologique

F Berger

Correspondence to:

Dr D Pansu, Ecole Pratique des Hautes Etudes,

INSERM U45, Pavillon Hbis

Hôpital Edouard Herriot,

69437 Lyon Cedex 03,

France.

Accepted for publication 21 July 1999

Keywords: carcinoid tumours; human; insulinoma; intestine; pancreas; sorbin

Sorbin is a 153 amino acid peptide isolated from porcine upper small intestine and purified taking into account the increase in water absorption in the guinea pig gall bladder. ${ }^{1}$ Its biological activity, shown in the rat, includes increasing duodenal absorption under basal condition $\mathrm{s}^{2}$ and decreasing vasoactive intestinal peptide (VIP) induced and cholera induced intestinal secretion..$^{3-5}$ The proabsorptive effect and antisecretory effect have been shown in human colon in vitro. ${ }^{6}$ The C-terminal heptapeptide-amide of the natural molecule (C7- $\mathrm{NH}_{2}$ sorbin) was the smallest biologically active fragment. The antisecretory effect was equivalent to that observed with Met- enkephalinamide and angiotensin in our experimental conditions, ${ }^{2}$ but sorbin did not have their motor and vasomotor effects. Sorbin was localised by immunohistological methods in the porcine gastro-entero-pancreatic system using two polyclonal antibodies raised against $\mathrm{C}$-terminal and $\mathrm{N}$-terminal sequences of the whole molecule. Both antibodies disclosed sorbin immunoreactivity in endocrine cells of the gastric and duodenal epithelium. Sorbin positive cells were numerous at both sides of the pyloric junction, in the pyloric glands of the antrum, and in the duodenal crypts of Lieberkühn. Their number decreased aborally, and sorbin immunoreactivity was absent from the colonic mucosa. All sorbin positive cells contained serotonin and were thus a subpopulation of the enterochromaffin cells. The nervous system from the small and large intestine showed immunoreactivity against the C-terminal antibody. In the pancreas, the C-terminal part of the peptide was found in insulin-secreting cells and in a few epithelial cells of the duct of Wirsung.

In this study, immunoreactive sorbin was identified in normal human digestive tract. As sorbin immunoreactivity was found in intestinal serotonin-containing cells, its presence was explored in intestinal carcinoid tumours. In the same way, the sorbin immunoreactivity in pancreatic islets prompted us to explore its presence in pancreatic endocrine tumours. Fourteen intestinal carcinoid tumours and 23 pancreatic tumours including six insulinomas were tested for sorbin immunoreactivity. Results on the localisation of sorbin-producing structures in the intestine and pancreas are presented, as well as the immunohistological characteristics observed in ten sorbin positive tumours. The pathological implication of the presence of sorbin in endocrine tumours was assessed by a retrospective study of patient clinical history.

\section{Methods}

COLLECTION OF HUMAN SAMPLES

All tissue material came from surgical resections. Normal specimens from the pyloric junction, duodenum, jejunum, ileum, ascending and descending colon, and pancreas were distal parts of surgical resections for carcinoma. Thirty seven endocrine tumours were selected from the anatomical files of patients operated on between 1986 and 1995. The histopathological control of surgical pieces had been previously performed by FB. Carcinoid tumours had been identified by the argy-

Abbreviation used in this paper: VIP, vasoactive intestinal peptide. 
rophilic and argentaffin properties of the tumoral cells, insulinoma by immunohistological identification of insulin, other pancreatic tumours by the positive argyrophilic reaction, the malignancy of the tumoral tissue, and identification of their endocrine product. Sections were prepared from the blocks from which the histopathological diagnosis had been made.

\section{PATIENT HISTORIES}

These were obtained from the surgical files. The clinical history was documented in 28 patients, and follow up until 1998 in 18 of them.

IMMUNOHISTOCHEMICAL METHODS

Detection of sorbin with two antibodies raised against the $\mathrm{C}$-terminal and $\mathrm{N}$-terminal sequences of porcine sorbin previously tested in the pig $^{6}$ was performed in normal tissues, in intestinal carcinoid tumours, and in pancreatic endocrine tumours. Detection of serotonin and chromogranin A was performed in the section adjacent to that used for detection of sorbin. Pancreatic tumours were studied with a panel of antibodies (table 1) raised against insulin and other neurohormonal peptides, provided by specialist firms or raised in our laboratory. ${ }^{8-10}$

\section{PREPARATION OF SORBIN ANTISERA}

Sorbin antisera were prepared from two synthetic peptide sequences of sorbin: $\mathrm{N}$-terminal (8-18) and C-terminal amidated (137-153) (fig 1). The N-terminal and C-terminal antibodies were raised in rabbit. Immunohistological controls were previously performed on porcine tissue. ${ }^{7}$ Briefly they involved: omission of the primary antiserum; substitution of the primary antiserum with non-immune serum; higher dilutions of the primary antiserum (up to 1:2000); influence of the saline concentration (up to $0.5 \mathrm{M}$ ) in the buffer; complement deprived antiserum obtained by heating at $56^{\circ} \mathrm{C}$ just before use. The specificity of C-terminal and $\mathrm{N}$-terminal sorbin antisera was verified by preadsorption (60 minutes at $37^{\circ} \mathrm{C}$ ) to the homologous peptide at a concentration of $1 \mu \mathrm{mol} / \mathrm{ml}$ of undiluted antiserum. Cross reactivity was assessed with heterologous peptides known to be present in the porcine digestive tract in concentration intervals from 1 to $10 \mu \mathrm{mol} / \mathrm{ml}$ of undiluted antiserum. ${ }^{7}$ A radioimmunoassay was performed to evaluate the C-terminal sorbin

Table 1 Source and dilutions of antisera

\begin{tabular}{lllllll}
\hline Antisera & Dilution & Species & Type & Source & Reference & Microwaves \\
\hline Sorbin C-terminal & 1 in 500 & Rabbit & $\mathrm{P}$ & Abou El Fadil & (T5) 7 & Yes \\
Sorbin N-terminal & 1 in 250 & Rabbit & $\mathrm{P}$ & Abou El Fadil & (10E) 7 & Yes \\
Chromogranin A & 1 in 200 & Mouse & $\mathrm{M}$ & Boehringer & No 1199021 & No \\
Calcitonin & 1 in 3000 & Rabbit & $\mathrm{P}$ & Dako & No A576 & No \\
Insulin & 1 in 2000 & Mouse & $\mathrm{M}$ & ICN & No 691161 & No \\
SRIF 14 & 1 in 6000 & Rabbit & $\mathrm{P}$ & Chayvialle & (55A) 8 & No \\
Glucagon & 1 in 5000 & Mouse & $\mathrm{M}$ & Sigma & No G2654 & No \\
PP & 1 in 5000 & Rabbit & $\mathrm{P}$ & Bosshard & (28A) 9 & No \\
Serotonin & 1 in 200 & Mouse & $\mathrm{M}$ & Dako & No M758 & Yes \\
Gastrin & 1 in & Rabbit & $\mathrm{P}$ & Miazza & (28E) 10 & No \\
& 20000 & & & & & \\
PTH & 1 in 50 & Rabbit & $\mathrm{P}$ & Calbiochem & No 51225 & No
\end{tabular}

P, polyclonal; M, monoclonal; PP, pancreatic polypeptide; SRIF 14, somatostatin 14; PTH, parathyroid hormone.
MRAATPLQTVDRPKDTYKTMFKQIHMVHKPDDDTKMYNTP. L_8.18

YTYNAGLYNSPYSAQSHPAAKTQTYRPLSKSHSDNGTDAF-

KDASSPVPPPHVPPPVPPLRPRDRSSTEKHDRDPPDRKVD-

TRKFRSEPRSIFEYEPGKSSILQHERPVTKPQA-NH ${ }_{2}$

${ }_{1}^{137.153}$

Figure 1 Amino acid sequence of sorbin showing positions of synthetic peptides used for raising antibodies.

antiserum, using the binding properties of a synthetic peptide of 18 amino acids including the 17 terminal amino acids with the addition of tyrosine in position 1 (molecular mass 2028 Da; Y-C17- $\mathrm{NH}_{2}$ sorbin; Neosystem, Strasbourg, France). The specific activity of the tracer, the ${ }^{125}$ I-Tyr]C17 amidated peptide, was $74 \mathrm{TBq} / \mathrm{mmol}$ at the shipping date (Amersham, Les Ulis, France). The 50\% inhibition dose was $0.25 \mathrm{ng} /$ assay - that is, $2.5 \mathrm{pmol} / \mathrm{ml}$ and intra-assay and interassay coefficients of variation were $7 \%$ and $20 \%$ respectively. ${ }^{11}$

For the human material, controls were performed on normal and tumoral tissues; they included omission of the primary or secondary antiserum, and absence of adsorption of both antisera on $1-10 \mu \mathrm{mol} / \mathrm{ml}$ serotonin and insulin. For each patient, tissue sections were exposed to $\mathrm{C}$ - and $\mathrm{N}$-terminal antisera previously inactivated by adsorption to their respective homologous peptide; the molarity of the antigen was 10 and $20 \mu \mathrm{mol} / \mathrm{ml}$ pure antibody ( $37^{\circ} \mathrm{C}, 60$ minutes).

IMMUNOHISTOCHEMICAL STAINING

This was performed using the amplification kit Dako StreptABComplex/HRP Duet (Dako, Trappes, France). Sections ( $4 \mu \mathrm{m}$ thick) were mounted on glass slides precoated with $0.1 \%$ poly-L-lysine (Sigma, Saint Quentin Fallavier, France). They were deparaffinised and rehydrated. Endogenous peroxidase activity was blocked by a fresh 3\% solution of hydrogen peroxide in distilled water for five minutes and washed in tap water. Microwave treatment was performed to visualise C-terminal and $\mathrm{N}$-terminal sorbin and serotonin: tissue sections placed in a beaker filled with $0.01 \mathrm{M}$ sodium citrate buffer ( $\mathrm{pH}$ 6.0) were exposed to microwaves for $3 \times$ five minutes, then rinsed in $0.05 \mathrm{M}$ Tris/ $\mathrm{HCl}$ buffer containing $0.15 \mathrm{M}$ $\mathrm{NaCl}, \mathrm{pH}$ 7.6. The Dako Duet kit was adapted to the antibody: the C-terminal and $\mathrm{N}$-terminal antibodies were used at a dilution of 1:500 and 1:250 respectively, and the other antibodies were used at the dilutions indicated in table 1. The slides were incubated for 90 minutes in a humidity chamber at room temperature. The biotinylated goat antibody was incubated for 30 minutes at a dilution of 1:200 in Tris buffer. The biotinylated horseradish peroxidase and streptavidin were used at 1:200 dilution, mixed 30 minutes before use, and then applied to the slide for 30 minutes. Visualisation of peroxidase was achieved with 3,3'-diaminobenzidine tetrachloride (Dako). 
Several rinsing cycles in Tris buffer were performed between each incubation step. The sections were counterstained with haema-
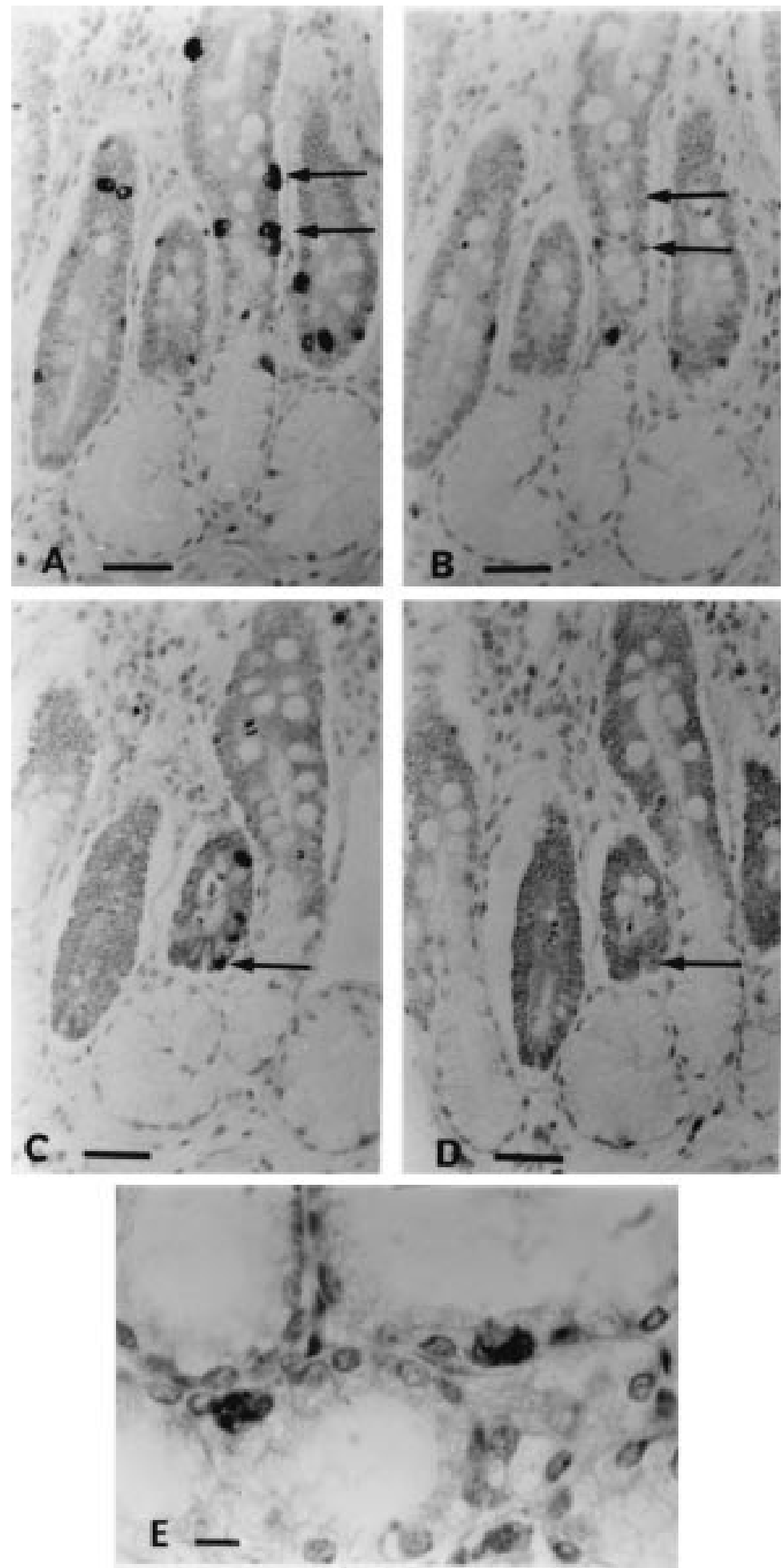

Figure 2 Localisation of sorbin immunoreactivity in the human duodenum. (A), (B), (C), and (D) are homologous fields of four adjacent sections. (A) Cells immunoreactive with the N-terminal sorbin antiserum. (B) Control, the immunoreactivity is partially blocked by adsorption on the homologous peptide, N8-18 peptide. (C) Cells immunoreactive with the $C$-terminal sorbin antiserum. (D) Control, the immunoreactivity is completely blocked by adsorption on the homologous peptide, $\mathrm{Y}-\mathrm{C} 17-\mathrm{NH}_{2}$ peptide. Sorbin positive cells are located in the crypts of Lieberkühn. C-Terminal immunoreactive cells appear less numerous because of better specificity and the use of a higher dilution (1:500) of the C-terminal antiserum. (E) Sorbin-containing cells in Brunner's glands. Bouin's fixation. Visualisation with StreptABComplex/HRP. Haematoxylin counterstain. Scale bar $=50 \mu \mathrm{m}$. toxylin. Argyrophilic and argentaffin cells were identified by the conventional Grimelius $^{11 \mathrm{a}}$ and Fontana-Masson ${ }^{1 \mathrm{~b}}$ procedure respectively.

The double immunostaining procedure used fluorescein isothiocyanate labelled goat antirabbit IgG to disclose the C-terminal sorbin antiserum, and tetramethyl rhodamine $\mathrm{B}$ isothiocyanate labelled goat anti-guinea pig IgG to disclose insulin.

\section{Results}

NORMAL HUMAN GASTROINTESTINAL TRACT In the small intestine (fig 2), positive cells were found in the crypts of Lieberkühn; they were numerous at the pyloric junction but also present in the jejunum and ileum. They were detected by both the $\mathrm{N}$-terminal antibody (fig 2A) and the C-terminal antibody (fig 2C). The N-terminal immunoreactivity was partially blocked after incubation with the homologous $\mathrm{N}$-terminal peptide (fig 2B), whereas the disappearance of the reaction with the C-terminal antibody was complete with the homologous peptide (fig 2D). A larger amount of the N-terminal immunoreactive cells was observed. This could be related to either the use of a higher concentration of the N-terminal antiserum or to a less specific reaction in the duodenum. The immunoreactive cells were abundant in Brunner's glands (fig 2E). A few sorbin positive cells were found in the antral mucosa adjacent to the pylorus. In the ascending and descending colon, numerous sorbin positive cells were present, immunoreactive with both antisera. Figure 3A,B shows the visualisation of sorbin cells by the N-terminal antibody and the complete disappearance of the reaction on the adjacent section treated with antiserum adsorbed on the $\mathrm{N}$-terminal peptide. In the enteric nervous system, immunoreactivity to the C-terminal but not the $\mathrm{N}$-terminal antibody was found in perikarya of numerous myenteric plexii from the duodenum to the ascending colon (fig 3C). Sorbin cells from the epithelium and myenteric plexii (fig 3D) were chromogranin positive. As in the pig, all sorbin positive cells from the intestinal epithelium contained serotonin and were a subpopulation of the enterochromaffin cells. As seen in fig 4A,B, only some of the serotonin positive cells contained sorbin.

In the pancreas, the C-terminal antibody disclosed immunoreactive cells in the islets of Langerhans, with a complete block when the antiserum was adsorbed on the homologous peptide (fig 5A,B). Double immunostaining showed that some cells were positive for both sorbin (fig 5C) and insulin (fig 5D). Cells containing sorbin did not exhibit serotonin immunoreactivity.

\section{ENDOCRINE TUMOURS}

Five of 14 intestinal carcinoids, two of six insulinomas, and three of 17 other pancreatic endocrine tumours expressed sorbin. The recruitment was performed from the anatomical samples, so the macroscopic and microscopic characterisation of sorbin negative and 

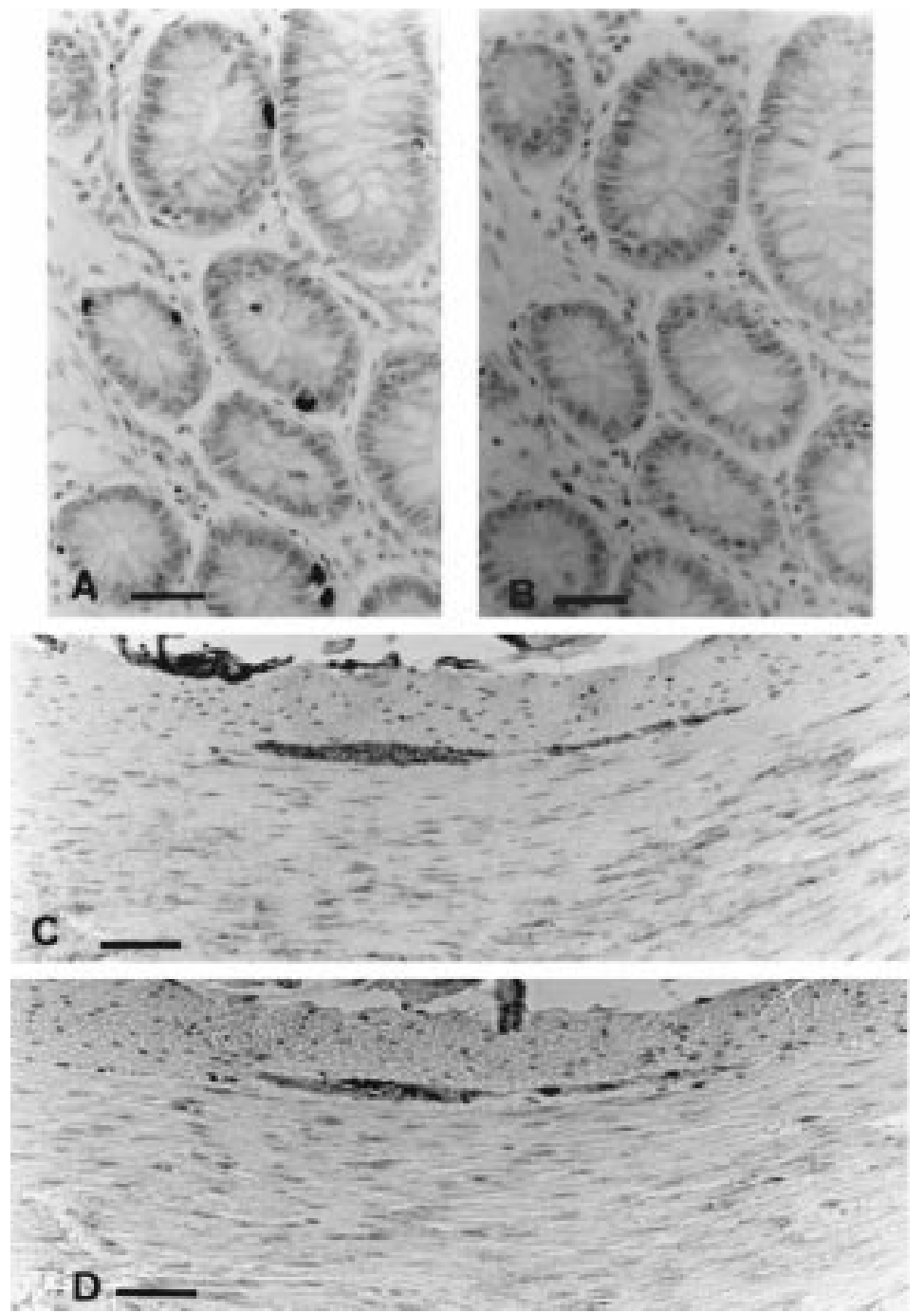

Figure 3 Sorbin localisation in human ascending colon. (A) Sorbin-containing cells disclosed by the N-terminal antiserum in the colonic glands. (B) Control. On the adjacent section, the reaction was completely blocked after adsorption of the antiserum by the homologous peptide. (C) Immunoreactivity to $C$-terminal antiserum of a colonic myenteric plexus. (D) Colocalisation with chromogranin in the same plexus (adjacent section). Bouin's fixation. Visualisation with StreptABComplex/HRP. Haematoxylin counterstain. Scale bar $=50 \mu \mathrm{m}$. ence of small nodes separated by connective tissue in the mucosa, the submucosa, and mesentery. The cells appeared homogeneous; mitotic figures and cellular atypia were rare, and some cells were argyrophilic, argentaffin, and chromogranin positive. Serotonin immunoreactivity was predominantly located at the periphery of the nodes; the number of serotonin positive cells varied from a few to an extensive response. In the five sorbin positive tumours, sorbin positive cells were detected by the $\mathrm{C}$ - and $\mathrm{N}$-terminal sorbin antibodies. The lack of detection in the presence of the preadsorbed antibody was controlled in each case. Figure $6 \mathrm{~A}-\mathrm{F}$ shows the typical appearance observed in two patients. Figure 6A shows the location of serotonin positive cells, which are more numerous at the periphery of the node. Figures $6 \mathrm{~B}$ and $6 \mathrm{C}$ are two consecutive sections showing cells positive for both the Nand C-terminal antibodies, and located in the centre of the node (patient no 3). Figures 6D, $6 \mathrm{E}$, and $6 \mathrm{~F}$ show serotonin, N-terminal and C-terminal immunoreactivity in patient no 1 with quite similar features. Figures $6 \mathrm{G}$ and $6 \mathrm{H}$ show the visualisation and blocking of C-terminal immunoreactivity in patient no 4 . In patient no 5, we found colocalisation of sorbin and serotonin in the tumoral cells. With the exception of the immunoreactivity for sorbin, the histopathological characteristics of the sorbin positive tumours did not differ from those observed in the nine sorbin negative carcinoid tumours. In all patients with sorbin positive and sorbin negative tumours, sorbin was found in the enterochromaffin cells in the intestine adjacent to the tumour.

Table 2 summarises the clinical and biochemical characteristics of the 14 patients to see whether any differences were associated with the cellular expression of sorbin. The clinical histories showed slight differences between the two groups. Their median ages were 69.8 (range 61-73) and 63.8 (range 54-75) years respectively. The carcinoid syndrome was present less often in sorbin positive tumours in which the disease was discovered by the appearance of a tumoral mass or incidentally. The increase in serotonin in the blood was similar in the two groups, and the daily output of 5-hydroxyindoleacetic acid in the urine was low in spite of a normal renal clearance in two sorbin positive patients. The extension was identical, and liver metastasis was found in all but one patient in both groups. Information on the follow up was obtained for four sorbin positive and six sorbin negative patients. All patients improved after surgery. A recurrence occurred in the four sorbin positive patients during the following year: one died after three years, and the other three are well, four, eight, and nine years after the surgical treatment. In the group of six sorbin negative patients, one patient, in whom surgical treatment included hepatectomy, was well in 1998, two patients presented with a recurrence which was controlled by somatostatin three and five years after the onset of symptoms, one suffered from a recent aggravation, and two died from complications during tumoral progression. Thus the several tumours in the intestinal wall with a tumoral extension to the adjacent mesentery with fibrosis responsible for loop agglutination. The histological examination showed the pres- 

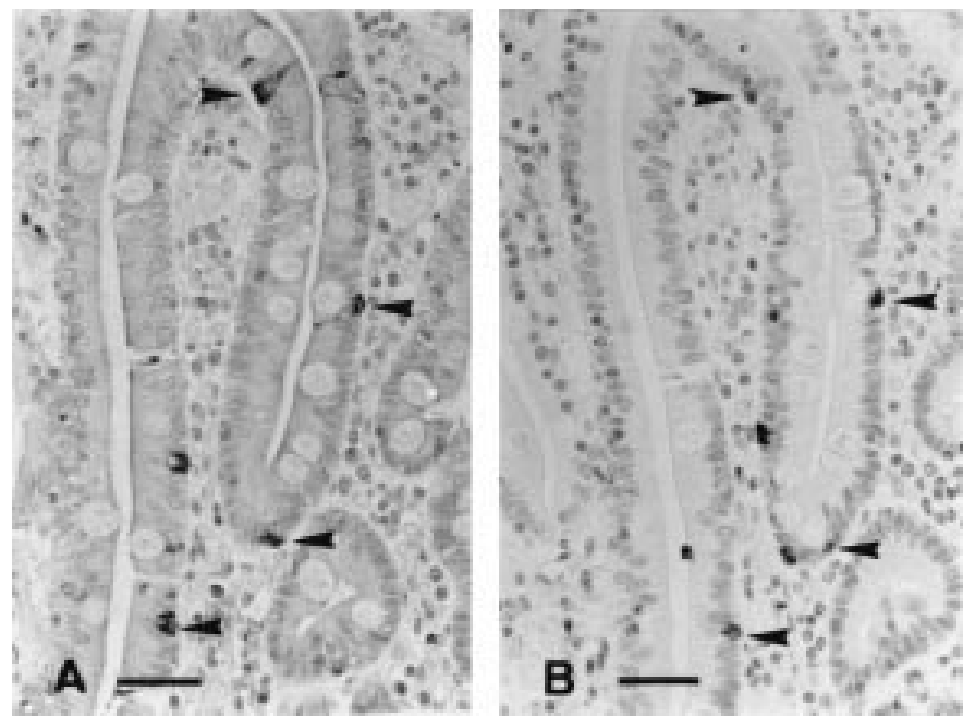

Figure 4 Colocalisation of sorbin $(A)$ and serotonin $(B)$ in enterochromaffin cells of the human duodenum shown by the topographical overlap in two adjacent sections (arrows). Scale bar $=50 \mu \mathrm{m}$.

\section{Pancreatic tumours}

Pancreatic tumours were separated into two groups: insulinomas and other neuroendocrine tumours, as the clinical emergency of hypoglycaemic crises contrasts with the other slowly growing tumours. The insulin negative group included 17 patients: eight with functioning tumours and nine with non-functioning tumours. Anatomically, the size of the tumour varied from a small nodule in the exocrine tissue near the ampulla of Vater to an enormous tumoral mass. Microscopically, the endocrine origin of the tumour was proved by the presence of some argyrophilic but not argentaffin cells; chromogranin A was found in nine of 12 patients who underwent the test. The immunological identification of the hormonal content did not always correlate with the presence or absence of clinical symptoms or excess circulating hormone.

Three patients (nos 6-8) had a sorbin positive tumour containing cells that were immunoreactive for the C-terminal antiserum of sorbin, the immunological reaction with the $\mathrm{N}$-terminal peptide being negative. In one case, the tumour was well differentiated, with large nodes organised into an insular pattern; some argyrophilic and chromogranin positive cells were found; about $20 \%$ of the cells expressed sorbin (fig 7A). In two cases, the tumour consisted of large nests, with some necrotic areas; the cells were an nosis when sorbin was expressed in the carcinoid tumour.
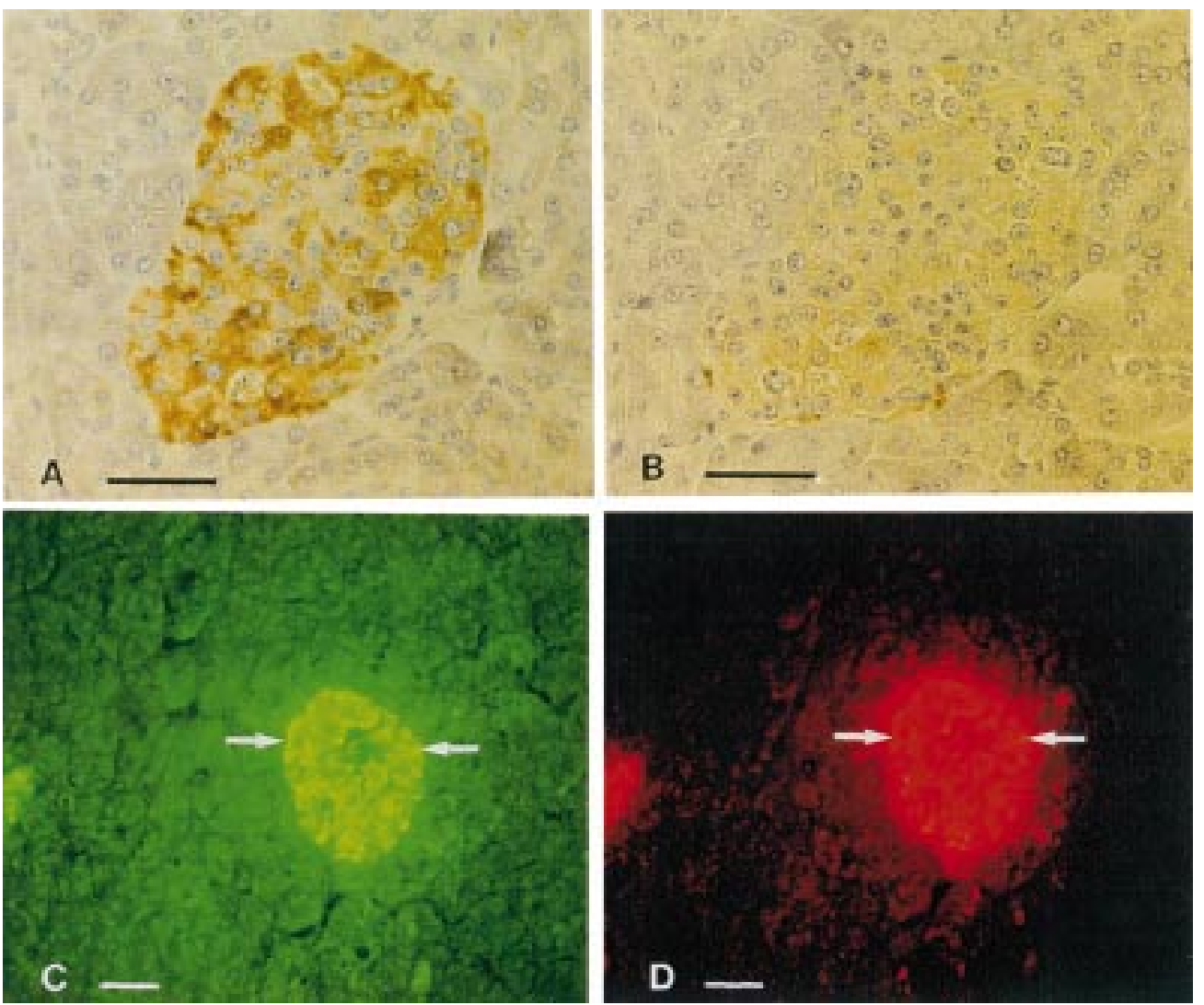

Figure 5 Sorbin immunoreactivity in islets of Langerhans of the human pancreas. (A) Sorbin-containing cells disclosed by the C-terminal antiserum. (B) Adjacent section: reaction completely blocked after adsorption of the antiserum on Y-C17-NH $\mathrm{N}_{2}$ sorbin. Bouin's fixation. Visualisation with StreptABComplex/HRP. Haematoxylin counterstain. (C) and (D) Double immunostaining of the same section using the fluorescein isothiocyanate labelled goat anti-rabbit IgG for sorbin (C) and the tetramethyl rhodamine B isothiocyanate labelled goat anti-guinea pig IgG for insulin (D). Cells are positive for both sorbin and insulin (arrows). Scale bar $=50 \mu \mathrm{m}$. 
irregular shape; the immunoreactivity for sorbin was weak in some cells and very intense in others (fig 7B). In all samples, the C-terminal peptide of sorbin was found in the endocrine islets, in the normal tissue, and in the pancreas adjacent to the tumour. Sorbin-producing cells were serotonin negative.

A comparison with sorbin negative tumours (table 3) shows that the age of discovery was not significantly different. In sorbin positive patients the pancreatic tumour was large with hepatic metastasis in two cases. The tumour expressed
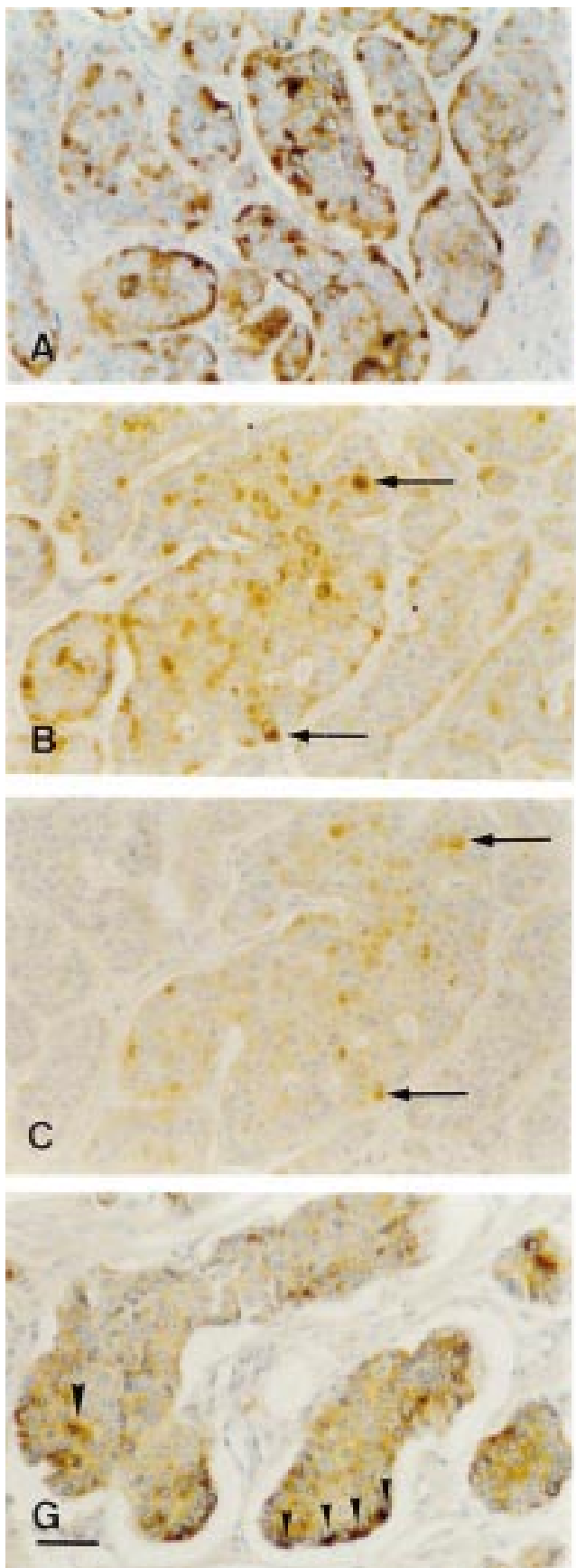

calcitonin (patient no 6), pancreatic polypeptide (patient no 7), and parathormone related peptide (patient no 8). However, sorbin was not found in the three tumours expressing calcitonin, pancreatic polypeptide, and parathormone related peptide - that is, peptides similar to those present in the sorbin positive patients. Sorbin was not present in tumours secreting gastrin (four cases), glucagon (three cases), or VIP (one case). The three sorbin positive patients were well three, five, and seven years after the onset of symptoms. From five sorbin
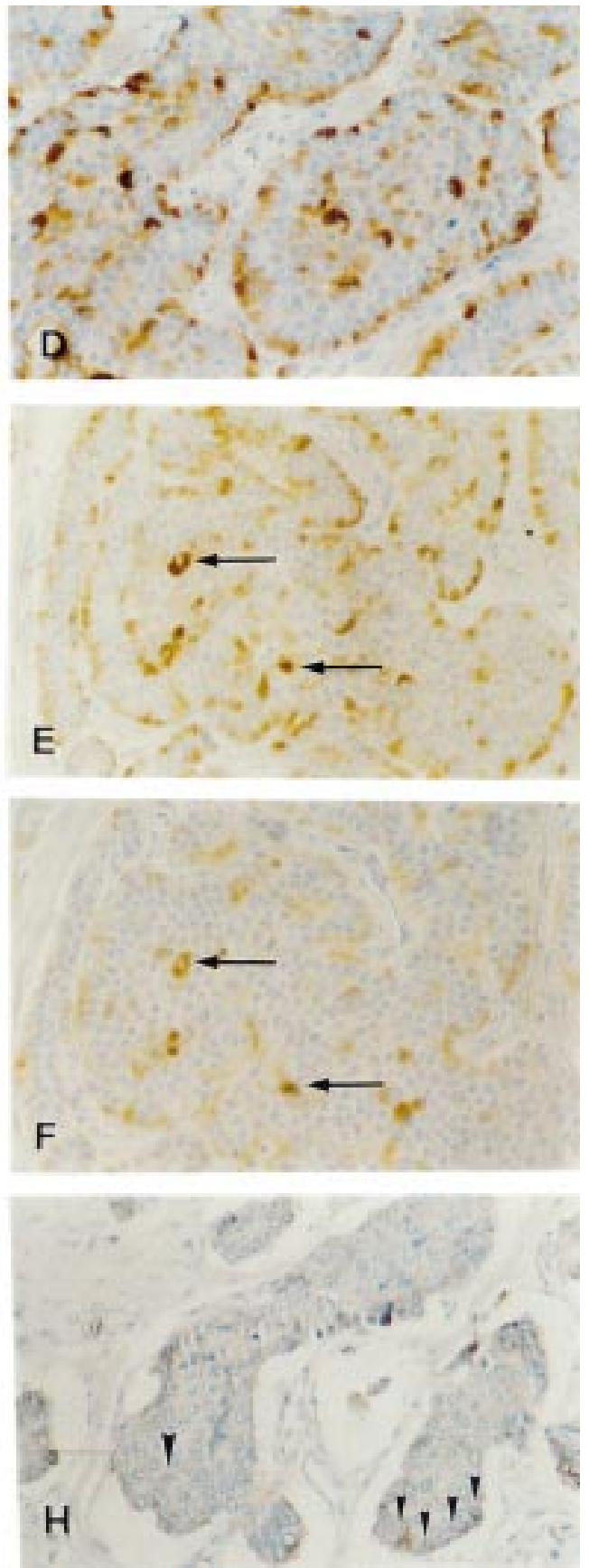

Figure 6 Intestinal carcinoid tumours. (A), (B), and (C) Patient no 1. (A) Serotonin immunoreactivity. (B) $N$-Terminal sorbin immunoreactivity. (C) Section adjacent to that in (B) showing $C$-terminal sorbin immunoreactivity; the same cell is expressing $N$ - and C-terminal immunoreactivity (arrows). (D), (E), and (F) Patient no 3. (D) Visualisation of serotonin. (E) N-Terminal immunoreactivity. (F) Section adjacent to that in (E) showing C-terminal immunoreactivity. The reaction is more intense with the $N$-terminal antiserum (dilution 1:250) than with the C-terminal one (dilution 1:500). The distribution of sorbin in the tumour is quite similar in the two patients. $(G)$ and $(H)$ Patient no 4. (G) Cells immunoreactive to the C-terminal antiserum. (H) Control, the immunostaining is blocked after adsorption of the antiserum on the homologous peptide (adjacent section) (arrows). Haematoxylin counterstain. Scale bar $=50 \mu m$. 
Table 2 Clinical and biochemical characteristics of patients wiht intestinal carcinoid tumours

\begin{tabular}{lll}
\hline & $\begin{array}{l}\text { Sorbin positive } \\
\text { tumours }\end{array}$ & $\begin{array}{l}\text { Sorbin negative } \\
\text { tumours }\end{array}$ \\
\hline $\begin{array}{l}\text { Number of patients } \\
\text { Sex }\end{array}$ & 5 & 9 \\
$\quad$ Men & 2 & 6 \\
$\quad$ Women & 3 & 3 \\
$\begin{array}{l}\text { Age (years) } \\
\text { Symptoms }\end{array}$ & $69.8(2.4)$ & $63.8(2.6)$ \\
$\quad$ Carcinoid syndrome & 2 & 5 \\
$\quad$ Occlusion & 0 & 1 \\
$\quad$ Abdominal tumour & 1 & 0 \\
$\quad$ Colonic disease & 2 & 1 \\
$\quad$ Unknown & 0 & 2 \\
Biological results & & \\
$\quad$ Serotonin $(\mu \mathrm{mol} /)^{\star}$ & $10.3(1.9)$ & $6.5(1.3)$ \\
$\quad$ 5HIAA ( $\mu$ mol/day) $\dagger$ & $278(143)$ & $549(114)$ \\
Extension & & 8 \\
$\quad$ Lymph node metastasis & 5 & 6 \\
$\quad$ Liver metastasis & 4 &
\end{tabular}

Where applicable values are mean (SEM); $\mathrm{n}=4$ for the biological results.

*Normal value $<1.5 \mu \mathrm{mol} / 1$; †normal value $<42 \mu \mathrm{mol} /$ day.

5HIAA, 5-hydroxyindoleacetic acid.

negative patients whose follow up was known, three died and two were well in 1998, seven and 10 years after the discovery of the disease. The scarcity of information about the progress of the sorbin negative patients did not permit us to suggest a different prognosis when sorbin was expressed in the pancreatic tumoral cells.

\section{Insulinomas}

Six pancreatic tumours expressing insulin were studied; two had sorbin positive cells. Four patients suffered from a typical benign insulinoma, one presented with an insulinoma during the course of multiple endocrine neoplasia type I, and one presented with a malignant insulinoma with hepatic metastasis. Anatomically the sorbin positive tumours
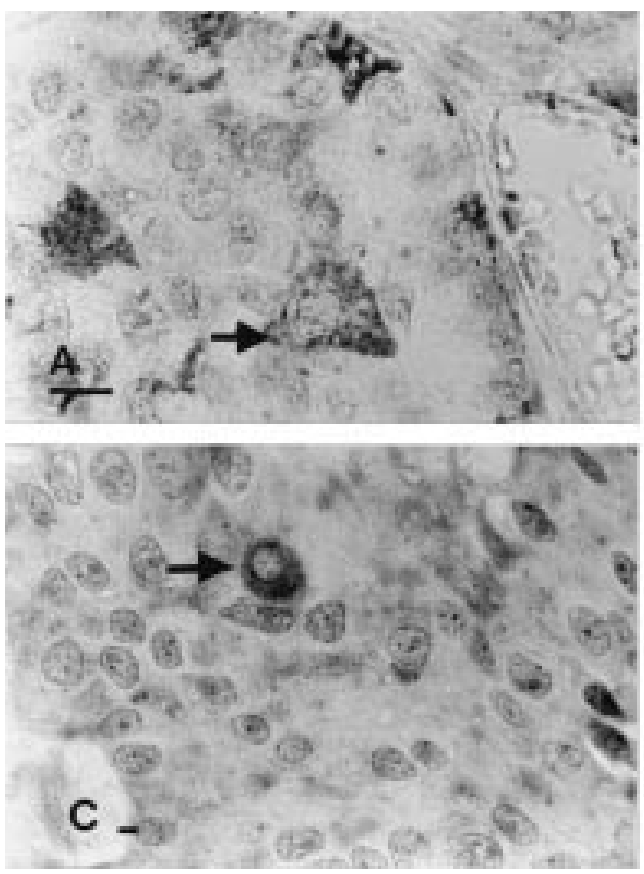

Table 3 Clinical and immunological characteristics of patients with pancreatic tumours

\begin{tabular}{lll}
\hline & $\begin{array}{l}\text { Sorbin positive } \\
\text { tumours }\end{array}$ & $\begin{array}{l}\text { Sorbin negative } \\
\text { tumours }\end{array}$ \\
\hline $\begin{array}{ll}\text { Number of patients } \\
\text { Sex }\end{array}$ & 3 & 14 \\
$\quad$ Men & 1 & 9 \\
$\quad$ Women & 2 & 5 \\
Age (years) & $58.7(7.7)$ & $48.2(3.7)$ \\
Symptoms & & \\
$\quad$ Zollinger-Ellison & 0 & \\
$\quad$ Gastrinoma & 0 & 4 \\
MEN-I & 0 & 1 \\
$\quad$ Diarrhoea (Vipoma) & 0 & 1 \\
$\quad$ Hypercalcaemia & 1 & 1 \\
$\quad$ Abdominal tumour & 1 & 1 \\
$\quad$ Abdominal pain & 1 & 1 \\
$\quad$ Unknown & 0 & 5 \\
Extension & & 5 \\
$\quad$ Lymph node metastasis & 2 & 5 \\
$\quad$ Liver metastasis & 2 & 6 \\
$\quad$ Unknown & 0 & \\
\hline
\end{tabular}

Where applicable values are mean (SEM).

MEN-I, multiple endocrine neoplasia type I.

(patients nos 9 and 10) were quite similar to the two other typical benign insulinoma: a small tumour, less than $2 \mathrm{~cm}$ in diameter implanted in the pancreatic exocrine tissue; the tumoral nodes contained cells organised into trabecules; rare mitoses; less than $20 \%$ immunoreactive for insulin. A few cells were immunoreactive for the C-terminal antibody of sorbin; they were not immunoreactive for the $\mathrm{N}$-terminal antibody. In fig 7C and 7D (patient no 10), sorbin immunoreactive cells (fig 7C) and insulin immunoreactive cells (fig 7D) are scarce.

Table 4 summarises the clinical characteristics of the six patients. The symptoms of two patients presenting with sorbin positive tumours did not differ from those of two other patients with a benign insulinoma: early
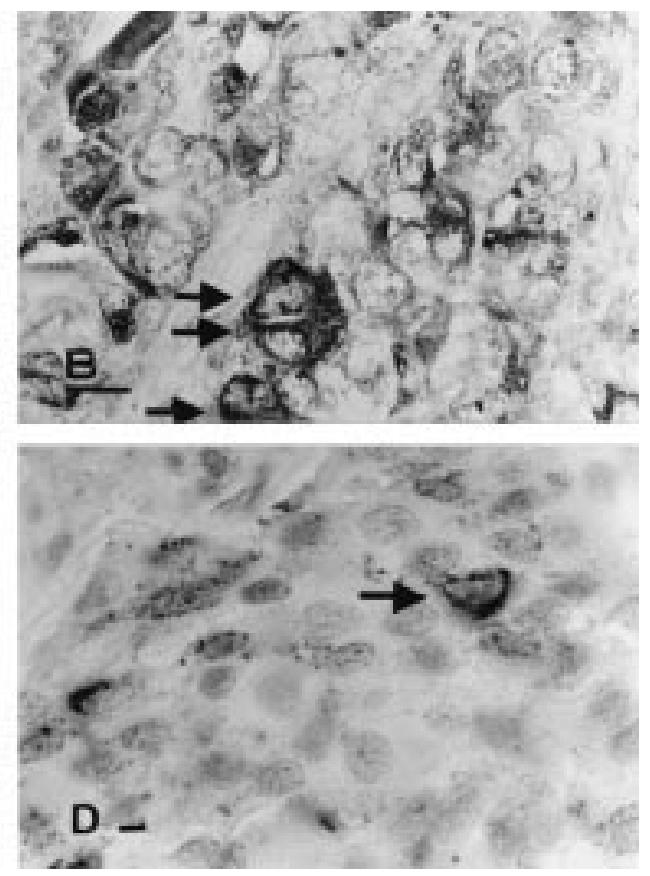

Figure 7 Pancreatic endocrine tumours. (A) Patient no 8, tumour secreting hypercalcaemic factor. The cell immunoreactive for the $C$-terminal sorbin antiserum (indicated by an arrow) has a large cytosol and medium immunoreactivity. (B) Patient no 6, tumour secreting calcitonin. The cells immunoreactive for $C$-terminal sorbin antiserum (indicated by arrows) have an irregular shape, large nucleus, and intense immunoreactivity. (C) and (D) Insulinoma, patient no 10. (C) Cell immunoreactive for the C-terminal sorbin antiserum (arrow); (D) insulin-containing cell (arrow). Haematoxylin counterstain. Scale bar $=10 \mu \mathrm{m}$. 
Table 4 Clinical and biochemical characteristics of patients with insulinomas

\begin{tabular}{lll}
\hline & $\begin{array}{l}\text { Sorbin positive } \\
\text { tumours }\end{array}$ & $\begin{array}{l}\text { Sorbin negative } \\
\text { tumours }\end{array}$ \\
\hline $\begin{array}{l}\text { Number of patients } \\
\text { Sex }\end{array}$ & 2 & 4 \\
$\quad$ Men & 1 & 2 \\
$\quad$ Women & 1 & 2 \\
Age (years) & $36.0(2)$ & $35.7(8.4)$ \\
$\quad \begin{array}{l}\text { Symptoms } \\
\quad \text { Hypoglycaemia }\end{array}$ & 2 & 4 \\
$\quad$ Others & 0 & MEN-I with \\
$\quad$ Extension & & ZE* \\
$\quad$ Lymph node metastasis & 0 & 2 \\
$\quad$ Liver metastasis & 0 & 1 \\
\hline
\end{tabular}

Where applicable values are mean (SEM).

*Hypoglycaemic crisis during the evolution of a multiple endocrine neoplasia type I (MEN-I) with Zollinger Ellison syndrome (ZE).

diagnosis after the beginning of the symptoms; absence of lymphatic or hepatic extension; complete recovery. Sorbin was not expressed in the insulinoma of the patient suffering from a familial multiple endocrine neoplasia type I syndrome, nor in a patient with a malignant insulinoma.

\section{Discussion}

The distribution of sorbin-producing cells has recently been described in the porcine gastrointestinal tract. ${ }^{7}$ The cellular localisation of sorbin has been explored in normal human intestine and pancreas using two antibodies raised against the $\mathrm{C}$-terminal and $\mathrm{N}$-terminal sequences of the 153 amino acid porcine peptide. ${ }^{1}$ In the human intestine, the sorbincontaining cells were immunoreactive for both antibodies, they contained serotonin, and were a subpopulation of enterochromaffin cells. This distribution was slightly different from that found in the pig $^{7}$ and rat. ${ }^{12}$ In the human gastrointestinal tract, sorbin-containing endocrine cells were found at each level of the small and large intestine; they were very rare in the antrum. In the pig, sorbin-containing cells were found in the fundus, antrum and the duodenal side of the pylorus; their number decreased aborally and they were absent from the colon. In the rat, sorbin cells were found exclusively on both sides of the pylorus; they were immunoreactive for the purified C-terminal antibody only. In the three species, the sorbin cells in the pancreas were a subpopulation of insulin cells; they were immunoreactive for the C-terminal antiserum only. These cells contained serotonin in the pig but not in human and rat. Likewise, in the three species, the enteric nervous system was immunoreactive for the C-terminal antiserum but not for the $\mathrm{N}$-terminal antiserum. The absence of immunoreactivity with the $\mathrm{N}$-terminal antiserum in pancreatic cells and the enteric nervous system suggests that at least two forms of sorbin are detected, possessing the same C-terminal region. However, the minimal active sequence of sorbin that increases intestinal absorption and decreases induced intestinal secretion includes the seven C-terminal amino acids, ${ }^{11}$ and is well represented in the nerves and endocrine pancreas in the three species, as in the intestine.
The diversity of products from endocrine digestive tumours has been largely described. ${ }^{13-16}$ In this study, 37 endocrine tumours were explored; ten of them contained sorbin. The presence of sorbin in enterochromaffin cells made the presence of immunoreactivity for sorbin in serotonin-secreting tumours highly probable; five of 14 were found to be sorbin positive. In the human pancreas, sorbin is expressed in insulin-containing cells, and we found two of six insulinomas that contained sorbin. For the other pancreatic tumours, no relation was found between the major peptide expressed and the presence of sorbin. Each tumour secreted one predominant peptide: calcitonin, pancreatic polypeptide, hypercalcaemic peptide (probably parathormone related protein). The absence of sorbin from tumours containing a majority of glucagon positive cells and tumours secreting gastrin-like peptide or VIP is in accordance with the colocalisation described for normal tissue: sorbin was not colocalised with gastrin in antrum, nor with glucagon in pancreatic islets or VIP nerves (unpublished work). We did not identify any clinical sign related to the presence of sorbin. The best known biological action of the C-terminal peptide of sorbin is a proabsorptive and antidiarrhoeaic effect, which was not found in this small series. In seven sorbin positive patients for whom the follow up results were known, six were well in 1998, whereas only five of the 11 sorbin negative patients were alive in 1998; a study of a larger number of tumours would elucidate whether the presence of sorbin, indicating further differentiation, is related to minor malignancy. On the other hand, when resectable hepatic metastases were treated by segmentary hepatectomy, the prognosis was better, as all six patients treated by hepatectomy were alive in 1998. The benefit ensured by hepatectomy is demonstrated in this series, as previously shown ${ }^{17}$ and confirmed. ${ }^{18} 19$

Grant support came from the Institut Henri Beaufour (to FAEF). Part of this work was presented at the 11th International Symposium on Regulatory Peptides, Copenhagen, September 1-3, 1996. We thank Marie Tedone and Christine Remy for skilful technical assistance, A Bosshard and MA Dechelette for their advice, Professor $C$ Partensky for giving us access to the surgical records, and Professors J A Chayvialle, L Descos, P Paliard, and tal Edouard Herriot, Lyon, France) for their help.

1 Vagne-Descroix M, Pansu D, Jornvall H, et al. Isolation and characterisation of porcine sorbin. Eur $\mathcal{F}$ Biochem 1991;201:53-9.

2 Charpin G, Chikh-Issa AR, Guignard H, et al. Effect of sorbin on duodenal absorption of water and electrolytes in the rat. Gastroenterology 1992;103:1568-73.

3 Marquet F, Grishina O, Pansu D, et al. Effet des dérivés C-terminaux de la sorbine sur les flux ioniques ileaux stimulés par le VIP chez le rat. Gastroenterol Clin Biol 1994;18: $702-7$

4 Grishina O, Charpin G, Marquet F, et al. Effet des dérivés C-terminaux de la sorbine sur les flux ioniques duodénaux chez le rat. Gastroenterol Clin Biol 1995;19:487-93.

5 Marquet F, Botella A, Bueno L, et al. Effect of sorbin derivatives on cholera toxin-induced intestinal secretion in rat in vivo. Peptides 1998;19:1417-23.

6 Eto B, Griesmar B, Desjeux JF. Effect of sorbin on electroyte transport in rat and human intestine. Am $\mathcal{f}$ Physiol 1999; 276:G107-14

7 Abou El Fadil F, Nicol P, Leduque P, et al. Sorbin in the porcine gastrointestinal tract and pancreas: an immunocytochemical study. Endocrinology 1997;138:4989-99.

8 Chayvialle JA, Miyata M, Rayford PL, et al. Immunoreactive somatostatin and vasoactive intestinal peptide in the digessomatostatin and vasoactive intestinal peptide in the
tive tract of cat. Gastroenterology 1980;79:837-43.

9 Bosshard A, Chéry-Croze S, Cuber JC, et al. Immunocytochemical study of peptidergic structures in Brunner's glands. Gastroenterology 1989;97:1382-8. 
10 Miazza B, Palma JR, Lachance JR, et al. Jejunal secretory effect of intraduodenal food in humans. Gastroenterology 1985;88:1215-22.

11 Nicol P, Vienet R, Jourdan G, et al. Pharmacokinetic, metabolic and anti-diarrheal properties of (D \& L) heptapeptides of sorbin in rodents. Peptides 1995;16: $1343-50$

11a Grimelius L, Wilander E. Silver stains in the study of endocrine cells of the gut and pancreas. Cell Pathol 1980 3:3-12.

11b Singh I. A modification of the Masson-Hamperl method for staining of argentaffin cells. Anat Anz 1964;115:81-2.

12 Abou El Fadil-Nicol. Distribution de la sorbine dans le tractus digestif du porc, du rat et de l'homme. Thèse Universite Claude Bernard, Lyon 1, 1997 .

13 Yang $\mathrm{K}$, Ulich $\mathrm{T}$, Cheng $\mathrm{L}$, et al. The neuroendocrine products of intestinal carcinoids. An immunoperoxidase study of 35 carcinoid tumours stained for serotonin and eight
14 Alumets J, Sundler F, Falkmer S, et al. Neurohormonal peptides in endocrine tumours of the pancreas, stomach, and upper small intestine. I. An immunohistochemical study of 27 cases. Ultrastruct Pathol 1983;5:55-72.

5 Hammond PJ, Polak JM, Bloom SR. Miscellaneous tumours of the pancreas. In: Go VLW, DiMagno EP, Gardener JD, et al, eds. The pancreas: biology, pathobiology, and disease, 2nd ed. New York: Raven, 1993:997-1007.

16 Perry RP, Vinik AI. Endocrine tumors of the gastrointestinal tract. Annu Rev Med 1996;47:57-68.

17 Partensky C, Landraud R, Velecela E, et al. L'exérèse des tumeurs carcinoÏdes de l'intestin grêle reste indiquée en présence de métastases hépatiques diffuses. Ann Chir 1990;44:34-8.

18 Que FG, Dagorney DM, Batts KP, et al. Hepatic resection for metatstatic neuroendocrine carcinomas. Am 7 Surg 1995;169:36-43.

19 Madeira I, Terris B, Voss M, et al. Prognostic factors in patients with endocrine tumors of the duodenopancreatic patients with endocrine tum
area. Gut 1998;43:422-7. 